\title{
História e memória em \\ (dis)curso: Fernando Catroga \\ e a poética da ausência
}

pg $127-145$

Maria Cleci Venturini ${ }^{1}$

\section{Resumo}

O foco de nossas discussões é a história e a memória em (dis)curso com vistas à interface com Fernando Catroga, por meio da noção poética da ausência, sintagma a que o autor recorre para destacar a dimensão subjacente ao jogo simulador e dissimulador que - tanto na simbologia e nos ritos funerários, como nas narrativas históricas, incluindo as construídas pela escrita historiográfica - visa dar uma mediata e mediada presença discursiva à ausência. O historiador é rigoroso em suas fontes, mas isso não significa aceitar, por exemplo, a distância entre a memória e a história. Assume posicionamentos e dá visibilidade a eles por meio de questionamentos e de metáforas que destacam a alteridade, a imaginação e elementos de ficção na história e na memória. Dentro dessa perspectiva, elegemos como objeto de estudo Inês de Castro e o fazemos por meio de lugares e de discursos em que ela ressoa, como o ausente, presente. Para dar conta do objetivo proposto, recortamos dois espaços públicos: a Quinta das Lágrimas, em Coimbra, e o seu túmulo no Mosteiro de Alcobaça e uma fonte escrita - o sermão das exéquias que procurou legitimá-la como rainha (póstuma) de Portugal e esposa de D. Pedro.

Palavras-chave: Discurso. Memória. História. Poética da ausência. Espaço público.

\section{HISTORY AND MEMORY IN DISCOURSE/PROGRESS: FERNANDO CATROGA AND THE POETICS OF ABSENCE}

\begin{abstract}
The focus of our discussions is about history and memory in discourse/progress viewing the interface with Fernando Catroga, by means of the poetics of absence notion, in which the author highlights the linguistic dimension to approach the funerary symbols that make present the absent. The historian is severe in his sources, but it does not mean accepting, for instance, the distance between memory and history. He assumes straight positions and makes it seen by the questions and metaphors that highlight the otherness, the imagination and fiction elements in history and memory. In this perspective, we choose Inês de Castro as a discursive object, and we do it by places and discourses in which she resonates as the absent, present. In order to meet the proposed objective, we selected two public places: Quinta das Lágrimas, in Coimbra, and her tomb in the Mosteiro de Alcobaşa, and a discourse - the funeral ceremonies sermon - that looks for legitimize her as queen of Portugal and D. Pedro's wife.
\end{abstract}

Keywords: Discourse. Memory. History. Poetics of absence. Public place.

1 Professora Associada A, Unicentro. Atua no departamento de Letras e na Pós-graduação em Letras. Estágio Sênior, na Universidade de Coimbra, sob a supervisão de Fernando Catroga. Bolsista Capes Processo BEX 0460/16-3, acordo Araucária/ Capes, edital 017/2015 
[...] o símbolo funerário é metáfora de vida e convite a uma periódica ritualização revivificadora; ele é para ser vivido e para ajudar a viver, oferecendo-se como um texto, cuja compreensão mais efectiva (a dos entes queridos) mobiliza, antes de mais, toda a subjectividade do sobrevivente.

Fernando Catroga

O céu da memória: Cemitério Romântico e Culto Cívico dos Mortos em Portugal

(1756-1911)

\section{Das razões do diálogo com Fernando Catroga: primeiras palavras}

A história, a memória e o espaço público há algum tempo têm sido mobilizadas em nossas pesquisas com foco em museus, arquivos $\mathrm{e}$ produção do conhecimento, desenvolvidas desde que iniciamos o nosso doutorado, na UFSM, em 2004 e defendemos a nossa tese em 2008. O foco inicial foi o Museu Érico Veríssimo, como o lugar de memória, que aglutina e centraliza a rememoração/comemoração do escritor no espaço urbano de Cruz Alta. O museu constitui-se como espaço material em que o tempo presente, passado e o futuro dão a "ver" e fazem "crer", conforme De Certeau (1984), a veracidade de um acontecimento, como histórico, mas também como ficção à medida que o museu ritualiza o nome presentificado, atendendo, muitas vezes, a razões institucionais ou de demandas do espaço urbano, na criação de um imaginário que atenda aos anseios dos sujeitos-cidadãos. Sandra Pesavento, no SEAD, Seminário de Análise de Discurso, realizado na Universidade Federal do Rio Grande do Sul, em 2005, foi quem nos deu a ler escritos do historiador Fernando Catroga, trazendo-o pelo conceito de memória cívica, que versava sobre fronteiras entre o que é individual e o que é social e também entre o 'eu' e o 'outro', como memórias fundadas na alteridade, fundamento existencial e antropológico para um melhor entendimento de conceitos como nação, nacionalidade e comemoração.
A princípio, e porque somos das Letras, como sempre digo, Catroga foi um grande desafio, pois conhecíamos pouco de sua obra. Mesmo assim, ousamos buscar seus textos e embarcar na 'aventura' de aprofundar a análise da sua obra e trajetória, tarefa difícil devido à densidade de suas discussões e das muitas referências que ela traz em seus textos, sempre alicerçando suas afirmações em filósofos e historiadores. Essa demanda também foi, e é, uma necessidade, porque na história - como diz Orlandi (2004) - objetivada no discurso como historicidade, ressoam acontecimentos, que podem estar na ordem do vivido ou do construído pelo discurso, sem se considerar relevante o fato de o discurso ou a narrativa ter, ou não, compromissos cognitivos com a veracidade ou com fontes e documentos. $\mathrm{O}$ mesmo ocorre com a memória, narrativa que, de acordo com Catroga (2001), não deixa de veicular pretensões à verosimilhança, mas onde é forte o peso de evocações imbuídas de sacralidade, subjetividade, afetividade, mas é menor a obrigação de provar e de comprovar o que é dito ou escrito pelo evocador. $\mathrm{Na}$ história (ciência), segundo Catroga (2009), a ausência também é re-presentificada pela linguagem e pela representância. Sem descurar, no entanto, o imperativo da prova e da demonstração, afinal a tecitura do próprio discurso historiográfico é o grande freio que divisa a imaginação historiográfica da imaginação estética, mesmo quando esta é exercitada a pretexto de fatos que aconteceram. $\mathrm{Na}$ Análise de Discurso, entendemos que o ausente pode significar a partir de um 'antes', em relação a, e na/pela história, como historicidade.

$\mathrm{Na}$ esfera dos nossos interesses, os temas sobre a presença e a ausência, a recordação e a comemoração se constituíram como a derradeira razão para adentrar a obra de Catroga. Em nossa investigação, colocamos em suspenso o imaginário urbano de uma pequena cidade que se vê na emergência institucional, social e histórica de presentificar Érico Veríssimo como filho daquela 
terra, como herança a ser dividida com todos, enfim, como um bem cultural, como patrimônio, tornando-o por meio do museu, de um mobiliário urbano, (dis)curso, uma presença (mediata e mediada), apesar da ausência. Nossa filiação à Análise de Discurso demandou a diferenciação entre o rememorar e o recordar, tendo em vista perspetivar a rememoração/comemoração como memória em (dis)curso, a partir de Pêcheux em seus muitos textos, mas principalmente, em Semântica e Discurso e por Orlandi, autora que fez de Pêcheux um ausente/presente na Análise de Discurso brasileira. Além de Orlandi e Pêcheux, outros teóricos nos ajudaram a pensar a memória. Foi o caso de Courtine (1999), no que tange aos eixos sintagmático e paradigmático, "mostrando" o intradiscurso e o interdiscurso como lugares de movimento de memórias, bem como o de Indursky (2003), com o destaque que deu ao discurso sempre permeado por outros discursos que o sustentam. A presença de "outros" discursos no discurso nos ajudou, assim, a compreender o discurso de, como a memória em (dis)curso, no eixo vertical, ancorando o discurso sobre, no eixo horizontal, e o consequente encontro/ desencontro desses (dis)cursos por meio da narrativa anamnética no eixo da formulação.

Como uma pesquisa e seus resultados não se constroem na homogeneidade, e porque a teoria costura-se e desloca-se devido a leituras advindas dos campos da antropologia, da história, da psicanálise e outros domínios, foram necessários deslocamentos com vistas a manter como eixo central o discurso, pensando em funcionamentos da memória, como discurso de e como discurso sobre. Convocamos Orlandi, Indurski, Mariani, em pesquisas que destacavam o discurso sobre o discurso do e que nos ajudaram a mostrar distintos efeitos de sentido e de relação entre ambos, e a compreender o discurso sobre, funcionando junto ao discurso de, como aquele que não pedagogiza, mas atualiza os sentidos e seus efeitos como memória, 'matéria-prima' que sustenta a interpretação. Falar sobre pode significar a atualização de sentidos, o tratamento de assuntos, mas não refere necessariamente a memórias que ressoam no intradiscurso - onde a recordação dá futuros ao passado pelo presente, que representa, re-presentifica o ausente (Catroga, 2009) -, mas mais a atividades de meta-memória carterizadoras da comemoração e das políticas da memória.

Para ilustrar esta correlação (e diferenciação), em textos de 2008 e 2009, desfizemos o par rememoração/comemoração e elaborámos um esquema 'explicativo' com duas colunas: uma para a rememoração e outra para a comemoração. Concomitantemente, interpretamos a rememoração como discurso de - memória - e a comemoração como discurso sobre, sendo a atualização desse discurso, ou, na terminologia de F. Catroga, bebida em Candau (1998), metamemória. Desse funcionamento, entendemos que a rememoração (discurso de) e a comemoração (discurso sobre) constituem-se em (dis)curso por meio de narrativas de vocação retrospectiva, definidas como "um fio que puxa outros fios e tece o discurso, o qual, pelos efeitos de verdade e de evidência, linearizase como saturado, constitutivo de memórias nãolacunares" (VENTURINI, 2009, p. 48). Por esta via, capta-se o que se repete como memória e por processos metafóricos, exteririzando-se em rede e em discursos que se atravessam por processos metonímicos que relevam, mesmo no que escondem e recalcam, as condicionalidades espácio-temporais que mediatizam a seleção do que se recorda e, sobretudo, do que de comemora. Não admira, pois desde Saussure se sabe que dois objetos ou ideias não ocupam o mesmo lugar, pois há o eixo das relações - o sintagmático - e o eixo das seleções - o paradigmático, sendo o primeiro horizontal (intradiscurso) e, o segundo, vertical (interdiscurso).

Refizemos esse caminho em (dis)curso para dizer que a história, a memória e o espaço público fazem parte da nossa pesquisa, e que Fernando Catroga foi uma referência importante, 
inicialmente, em relação ao tempo e à comemoração e, no estágio sênior, no que respeita à problemática da representância da ausência. Este alargamento que impôs a necessidade acrescida de trabalharmos no entremeio da História e da Análise de Discurso, mostrando que a história e a memória perpassam os dois campos. É que, apesar de enfoques e de pressupostos antagônicos, existem concordâncias e aproximações, cujas fronteiras não são estanques. Ao contrário, elas se movem e se imbricam, ainda mais quando os pesquisadores entendem que só através da mediação da linguagem e da sua materialização como re-presentação discursiva sobre o passado se poderá re-presentificar as ausências ontologicamente irreversíveis.

Dentre as pesquisas e textos de Fernando Catroga destacamos sua tese "Militância laica e descristianização da morte em Portugal (18651911)", defendida em 1988 e, sobremaneira o livro "Céu da memória: cemitério romântico e culto cívico dos mortos (1756-1911)", publicado em 1998, como parte de sua tese, em que Catroga buscou "apreender" o processo que conduziu à

\begin{abstract}
[...] revolução romântica dos cemitérios em Portugal e à transformação da necrópole num campo simbólico, isto é, num espaço público e afectivo, onde exemplarmente se passou a dramatizar e a delir a primordial tensão entre a exorável finitude humana e os sonhos (utópicos e ucrónicos) de superação do transcurso do tempo [...] e também mostrar como é que deste "fingimento", simultaneamente simulador de vida e dissimulador da prova ontológica da morte - o cadáver - nasceu a cenografia adequada ao crescimento e à produção e reprodução litúrgicas de uma instância julgadora que, em coabitação ou em alternativa com a escatologia judaico-cristã, se foi impondo com um novo além: a memória dos indivíduos e dos grupos. (CATROGA, 1999, p. 7)
\end{abstract}

A morte e as reproduções litúrgicas que simulam a vida são recorrentes em suas pesquisas e, de acordo com Marcelino (2017, p. 67), "O questionamento mais amplo sobre as formas diversas de ritualização da história [...] permitiu ao historiador português retomar as comparações que Michel de Certeau já havia estabelecido entre a historiografia e o rito de sepultamento", analogia também enfatizada por Ricouer (2007). No fundo, estamos perante a exploração do caminho aberto, no século XIX, por Michetet ao definir a (sua) escrita da História como uma 'ressurreição' de mortos, que encontram no texto o seu lugar e ordenação, e na sua leitura (como na da sepultura) o rito tanatológico apostado em preencher o vazio da ausência criada pela morte, como se, 'fingidamente' se acreditasse que as recordações pudessem ser 'a voz verdadeira do pretérito'. De acordo com Catroga (2009, p. 20), as recordações e as respectivas ritualizações dão futuros ao passado, numa atividade de representificação suscitada pelo diálogo entre os vivos e os mortos, ou, no caso do historiador, entre o presente-futuro do historiador e as interrogações que este coloca aos traços-vestígios que o passado, voluntária ou involuntariamente deixou quando foi um presente atravessado de expectativas de futuro. (CATROGA, 2009, p. 21). Nessa ótica, a memória não pode ser separada das expectativas em relação ao futuro, nem dos seus campos de objetivação (linguagem, imagens, relíquias, lugares, escrita, monumentos), enfim, dos ritos pelos quais ressoam os acontecimentos pretéritos, passíveis de serem reavivados, logicamente pelos vivos, a partir, quer de traços interiores que formam a memória vivida, quer dos traços ou vestígios materializados em suportes que parecem pedir aos que passam que lhes deem voz e façam justiça.

No texto "Os passos do homem como restolho do tempo: memória e o fim do fim da história", publicado em 2009, o autor continua a desenvolver pesquisas nessa direção. Daí que escreva Catroga (2009, p. 7): "trespassado de tempo, o caminhar do homem vai deixando traços no ecrã branco de Cronos que, ou serão sugados pelo Letes que é pior que a morte, ou, como no recalcado de cada existência, perdurarão - mesmo quando esquecidos ou não encontrados - como reserva de memória e história". Essas pegadas 
são traços que se mantêm e impedem o homem de ser só presente ou só futuro. Neste texto, o autor retoma com mais rigor a poética da ausência como uma linguagem que dissimula a ausência de corrupção para simular, num protesto contra a finitude, a eternização, garantida pela posteridade, do que ontologicamente já não é. E esse jogo se dissimulação e simulação é detectável tanto na narração histórica, como no ritualismo tanatológico e correspondente simbologia, sobretudo nas sociedades inumistas ocidentais.

Por essas razões, Fernando Catroga faz parte dos teóricos mobilizados em nossas pesquisas. Encontramos eco em suas obras para sustentar a concepção sobre a história e a memória em (dis)curso como duas noções que se diferenciam, mas mantêm aproximações bastante importantes, especialmente quando se discute práticas socias (e políticas) de cariz comemorativo e a inserção e filiação de sujeitos a lugares, não necessariamente a pátrias, mas a espaços memoriais. Catroga (2001), ao equacionar os elos entre a história/historiografia e a memória rejeita a existência de uma ruptura, para sublinhar as afinidades, mas também diferenças, entre os dois tipos de retrospectiva em pauta. No seu modo de ver, é demonstrável que, a montante, a historiografia não escapa a ser 'filha' da memória, legado que, todavia, tem de problematizar que incita à sua problematização. Mas, a juzante, as suas representificações, sobretudo quando se transformam em história transmitida e ensinável, também são 'filhas' da historiografia. No fundo, esta lição já estará implícita na mitologia grega, segundo a qual a musa da história - Clio - nasceu da união entre Zeus e Mnemosine, deusa da memória, dando origem a outras deusas gregas no monte de Hélicon. A história, filha da memória, durante muito tempo manteve laços com a lembrança de realizações humanas, dentre elas, a memória do povo, guardando os laços sanguíneos com Mnemosine no combate contra o esquecimento e a favor da preservação das realizações humanas.
A proximidade entre a história e a memória foi se descontruindo à medida que a história se tornou disciplina científica e sendo exigido dela um trabalho metódico, investigativo e reflexivo, alicerçado no método científico. A memória, contraditoriamente, foi sendo submetida a uma maior suspeição, por ser um produto mais espontâneo, mais pré-reflexivo, ressoando nela e por ela a continuidade, a individualidade e a sacralidade das heranças históricas. A preocupação com a cientificidade fez com que esses dois campos se distanciassem, devido ao destaque das diferenças e do apagamento das aproximações decorrentes dos usos que a história faz da memória. Fernando Catroga (2001) questiona e faz ressalvas à separação entre história e memória, tendo em vista a representificação do ausente, na alteridade, na síntese do passado que se realiza pelo fazer memorialístico e pela história. Para ele, a memória, não obstante a sua atualização e transmissão exigir a mediação subjetiva - só os indivíduos recordam -, é sempre social, pois ela não é própria, é sempre a memória de 'outro' na mente de um 'outro' que é um 'eu', resultado da alteridade e da inscrição dos sujeitos em diferentes campos memoriais. Em resumo, a memória é abertura ao outro e construtora do indivíduo como sujeito, pois, se não for assim, a base em que este assenta poderá ser destruída, dando lugar a um 'eu' narcísico e à quebra da alteridade. Segundo Catroga (2009, p. 31), “cada indivíduo não pode esquecer que só recordando os outros de si mesmo se recorda".

$\mathrm{Na}$ Análise de Discurso, lugar de nossa filiação, a língua se constitui na/pela história, pela inscrição dos sujeitos em formações discursivas e, pelo discurso sempre como processo, no qual o sujeito é o centro. Discursivamente, a memória e o esquecimento são constitutivos e a convocação da história é vista, não como uma ciência preocupada com a veridicção, mas como historicidade, aqui entendida como ecos, como rastros e vestígios do 
que ressoa do passado, como 'sobra', instaurando e produzindo efeitos no presente. A memória, por esse viés teórico, diferencia-se da história como ciência, conquanto se reconheça que ambas se relacionam com o passado a partir do presente e de um horizonte que a sua tradução discursiva pode ser enviesada pela hegemonia do sujeito detentor do poder e da voz, que impõem a sua ideologia, determinando o que deve ser rememorado/ comemorado e quem deve/pode determinar os modos de fazer e reproduzir memórias.

Quando se trabalha com museus, arquivos e produção do conhecimento em (dis)curso, a história funciona como um saber localizado nos entremeios, vindo a constituir-se, em função disso, como mecanismo que contribui para a compreensão dos processos e das articulações constitutivas do dizer em (dis)curso, cognitivamente credibilizados por meio de traços e de vestígios, instaurando contradições e antagonismos entre a pretensão de provar e a necessidade de conservar e de mostrar num contexto de monumentalidade. Por isso, nos interstícios do dito e do não dito, esses saberes seguem as 'pegadas' do homem, não como sinais, mas como marcas que ajudam a compreender os efeitos de sentidos e os processos de significação em função do que fica silenciado como censura ou como o que não é dito, mas é constitutivo e instaura sentidos e efeitos, conforme Orlandi (2002).

De tudo que já escrevemos, falta ainda dizer que Fernando Catroga, como historiador, mas, especialmente, como pesquisador prioriza na historiografia a dimensão linguística, visível na abundância de metáforas que usa com vistas a falar da historiografia, da morte e das fronteiras entre os campos do saber, as quais são sempre móveis, ausentes e, ao mesmo tempo, presentes, encaminhando para o contraditório e para o questionamento, dando visibilidade ou apagando divisões. A sua escrita mostra a preocupação com as fontes bibliográficas e históricas, destacando a circulação dos saberes históricos e fazendo em simultâneo a sua própria história, a que tem acrescentado uma permanente preocupação com as teorias da história e com as epistemologias postas em ação pelas escolas historiográficas.

A retomada constante da teoria e os questionamentos que promovem o avanço do conhecimento legitimam o seu percurso teórico e mostram que ele se inscreve nas fronteiras, talvez nos entremeios, perguntando pela relação entre a história e a memória, pelo ausente, sendo presença nos limites da história, da memória e da linguagem, destacando, também, o sujeito que 'conta e se conta' e ao fazer isso se 'diz', dando-se a ver. O contar-se, de acordo com Catroga (2009), é inerente a sujeitos (emissores) à narratividade e, em particular, aquele se plasma como o uso público da memória e em outos discursos que visam lutar contra a erosão do tempo e sua consequência maior: a produção do esquecimento. E, se este objetivo já era visível na oralidade das narrativas míticas, ela também se encontra no gênero que recorreu à escrita para evitar que se esquecesse o que se viu ou ouviu, como exemplarmente desde logo se detecta nas Histórias de Heródoto. É assim que, de acordo com Catroga, a memória e o esquecimento se exigem reciprocamente, referendando, o que também pensamos a partir da Análise de Discurso.

A riqueza metafórica é visível em seus textos, especialmente, nos que incindem sobre a temática da morte e, em concreto, naqueles que respeitam o significado túmulos e o jogo da dissimulação/ simulação da presença da irreversível ausência ontológica. Para Catroga (1999, p. 22), com efeito, "o símbolo funerário é metáfora de vida e convite a uma periódica ritualização revivificadora; ele é para ser vivido e para ajudar a viver". 'Trata-se, conforme destacamos, anteriormente, de uma analogia entre a visita ao cemitério e a escrita da história, constituindo-se como um modo de dar presença ao que já não existe, como um gesto de sepultura em 
que "o simbolismo funerário aposta na edificação de memórias e indicia a simulação de 'presença' do ausente a partir de traços que, em simultâneo, dissimulam o que se quer recusar: a putrefação do referente" (CATROGA, 2009, p. 38).

Nesse sentido, assim como a morte remete para o 'não ser', o monumento funerário pretende avivar memórias, mas escondendo o que, metafisicamente, todo o ser humano quer recalcar: a corrupção do corpo morto e, portanto, do tempo, para, como que domesticando as 'almas penadas', para que a sociedade dos vivos possa "gozar da protecção dos seus antepassados, definitivamente pacificados", evocando-os, seja no cemitério-livro, no discurso, ou no espaço público, para recordá-los e/ou comemorá-los, a fim “de se reconstituir a ordem social que a morte pôs em causa", (CATROGA, 2009, p. 38). Sublinha, ainda, que o cemitério, sendo a cidade dos mortos, dá-lhes um lugar e um significado nos intertextos da sua simbologia. Desse modo, como a escrita da história e da historiografia se constroem do presente-futuro em direção ao passado, será pertinente compará-la, na senda de De Certeau (1975) à funcionalidade social que carateriza os ritos tanalógicos, mormente aqueles que a "visita ao cemitério", ou mesmo no espaço público, as práticas de recordação e de comemoração atualizam. Por isso, em ambas se pode surpreender um análogo desejo essencial de se alcançar a vitória dos vivos sobre a morte, o que torna visível as afinidades que também existem entre o trabalho da memória e o trabalho do luto. Indo ao fundo das coisas, também escudado numa investigação empirica sobre a urbanização dos cemitérios românticos em Portugal, Catroga sustenta, explicitamente, que "A escrita da história, será, portanto, um túmulo para o morto na dupla acepção de o honrar e de o eliminar, ou talvez melhor, de o esconder" (CATROGA, 2009, p. 38). Assim sendo, a história, assim como a memória, contribuem para o trabalho do luto porque re- presentificar discursivamente o que já não existe e está ameaçado de cair no esquecimento é uma forma de pagar a dívida do presente em relação ao passado.

É certo que a história, pelo menos cultivada como historiografia, está para Catroga deontologicamente subordinada ao imperativo da prova e da veracidade. O historiador frisa, também, que, na atualidade, nenhum historiador avisado tem ilusões acerca do cariz não mimético das reconstituições que ela constrói e não deixa de destacarocontributo dado pelaimaginação nagênese dos problemas e das interpretações que a pesquisa faz a partir de "fatos' certificadas pela assunção primordial de uma atitude crítica face à falsidade, ou não, das 'fontes' que os sustentam. Segundo Catroga (2009), o historiador sabe que trabalha com um tipo de imaginação sujeita a controle, porque visa produzir efeitos dominantemente cognitivos sobre uma referencialidade que não se confunde com os vestígios deixados pelo passado quando foi presente. Nessas perspectiva, os próprios discursos memoriais não dispensam uma análoga finalidade cognitiva, pois aspiram ao verossímel, embora o seu critério de veracidade seja sobretudo testificado, não pela investigação documental e pela contra-prova exigência nuclear da retrospectiva historiográfica -, mas pela idoneidade dos evocadores.

Fernando Catroga inscreve-se e escreve no desafio destes cruzamentos, afastando-se do conforto de estar em domínios bem definidos, seguindo cânones e campos disciplinares enformados e fechados. Em relação a essas movências, interessam-nos a maneira como, teórica e historiograficamente, defronta e confronta as fronteiras entre a vida e a morte, logo, entre a memória e a história, o religioso e o profano, a cidade dos vivos e a cidade dos mortos, as temporalidades, o eu e o outro, a estética e a história, a ausência e a presença mediatizadas pelos discursos, enfim, entre a ficcionalização do passado e o contensioso que alimenta o sempre renovado compromisso 
historiográfico, não com a verdade, mas com a prova e, deste modo, com a veracidade.

A separação e a não separação entre os duplos é o que propomos ver/fazer/pensar, costurando/ descosturando por meio de deslocamentos entre as disciplinas demandadas pelo diálogo da Análise de Discurso e Catroga e na determinação das fronteiras possíveis ao sujeito, que está nos limites, no não-lugar. É bom compreender, como sinaliza Catroga, que as fronteiras existem para serem pisadas e até violadas devido à existência de divisões políticas e das feridas abertas, tanto na história como na ficção. As fronteiras aceitam os limites entre o real-histórico e a imaginação no âmbito da história e da memória, asserção que é particularmente válida no que respeita à presença, no interior das memórias individuais e sociais de 'fronteiras interiores' (Herder). Elas, por coação ou socialização, juntam/disjuntam as diferenças e as aproximações; elas fazem funcionar a fluidez da subjetividade com vistas à construção/ desconstrução do 'eu' por meio de movimentos da memória nas dimensões autobiográficas e históricas. Segundo Catroga (2001, p. 16), essas duas dimensões demarcam os limites entre a memória e a história e mostram como os saberes se transferem: de um modo mais subjetivo e em função do outro (na memória autobiográfica), ou de modo mais alargado, com vistas ao investimento social e ao atendimento das demandas da formação social (na memória histórica).

O passado, nessa perspectiva, só pode ser reconstruído por meio da representação, como representificação, mediata e mediada, do ausente. Em função desses pressupostos, pode-se afirmar que Catroga (1999, 2001, 2009) trabalha a memória e a história à luz das seguintes questões: 1) A memória e a historiografia não seriam tipos de "representificação do ausente"? 2) A busca pelo Outro por meio de alteridades, não seria objetivo comum tanto da empresa memorialística como do empreendimento historiográfico? 3) A memória e a história não apresentarão grandes sínteses do passado? Esses questionamentos permitem-nos sustentar que, para o autor, o fato de a memória e de a história realizarem de forma não coincidente suas empreitadas, não anula nem as analogias entre elas, nem as suas diferenças. Os questionamentos realizados mostram que o pesquisador não caiu no reducionismo ingênuo de igualar história e memória, mas também não advogou a favor de uma separação radical.

\section{Inês de Castro e a poética do ausente: Quinta das Lágrimas}

Como sinalizamos, anteriormente, a densidade da obra de Fernando Catroga e seus posicionamentos diante da história/historiografia, da memória e de espaços públicos, a abundância de referências, citações e ancoragens de seus textos, enfim, a amplitude e a densidade de tudo que escreveu obrigaram-nos a selecionar, a recortar e a demarcar o que dela é mais aplicável ao que aqui especificamente nos interessa: elevar o "caso Inês de Castro" a objeto discursivo para pensar as fronteiras entre a história, a memória e a ficção, isto é, entre o presente e o ausente, entre a crônica e o mito, abarcando desse modo, também o espaço público, o campo cemiterial e a separação entre o público e o privado. As delimitações elencadas permitem-nos discutir a poética da ausência, que dá visibilidade à mobilidade das fronteiras em funcionamento nos textos de Catroga. Poderíamos ter realizado outro recorte, mas o nome Inês de Castro chamou nossa atenção desde sempre. Inicialmente, pelos estudos de Literatura Portuguesa, com destaque para Camões, que fez dela um objeto estético, dando início ao mito que se mantém há muitos séculos.

E depois, pela perduração do ditado popular "Agora a Inês é morta", que circula em diferentes espaços e tempos e dá corporeidade ao nosso 
estranhamento diante desse nome, especialmente no Brasil, em que esse dizer constitui memória e se repete, recobrindo saberes, ainda que os elocutores desconheçam, ao certo, de que Inês se trata e que morte ecoa nesse dizer. A circulação do ditado, como fruto da sabedoria popular, é bastante instigante para os investigadores que concebem o discurso como o lugar em que outros discursos retornam pela memória, funcionando como um préconstruído, "termo construído por Paul Henry para designar o que remete a uma construção anterior, exterior, mas sempre independente, em oposição ao que é 'construído' pelo enunciado", conforme Pêcheux (1997, p. 99) ou como interdiscurso, definido por Pêcheux (1997) como o lugar onde estão todos os saberes e, por Courtine (1999, p. 18-19) como o lugar em que "não há um sujeito que lhe seja assinalável, que ressoa no domínio da memória somente uma voz sem nome".

O estranhamento que acabamos de explicitar é uma das razões para darmos relevância a Inês de Castro como objeto de pesquisa pelo viés da poética da ausência, a fim de mostrar como é que, através da linguagem, se concretiza a relação lógica de significação entre os símbolos funerários e a escrita da história. Os efeitos de presença e de dissimulação da perda de um lado e, de outro, a possibilidade de aproximar a Análise de Discurso, disciplina que se detém nas falas que as demais deixam de lado, é possível, já que tanto a narração historiográfica como o ritualismo e a simbologia tanatalógicos centram-se supõem uma referencialidade cuja ontologia remete, porém, para a categoria do ter sido (BERNARDES, 2004).

As aproximações são possíveis porque a Análise de Discurso trabalha no entremeio e não na perspectiva interdisciplinar, pois isso, de acordo com Orlandi (2004), seria reduzir disciplinas à função de instrumentos. É importante sublinhar, ainda, que Inês de Castro, também está nos entremeios, se olharmos pelo viés da historiografia. Com efeito, todos os discursos sobre ela pressupõem a existência de um referente, ou melhor, supõem, não só como uma personagem de ficção, mas também como um fato histórico comprovável, apesar de a História da Idade Média e a História de Portugal, apresentarem poucos documentos certificar ao pormenor. Mesmo assim, ela foi rastreada, primeiro pela crônica, depois encorporada na lenda e imortalizada como mito. No entanto, segundo Sousa (2005), há traços e indícios que provam a sua existência. Face a esta comprovação historiográfica e à concomitante ficcionalização construída sob o signo da tragédia, há lugar a que se pergunte: como e por que práticas ocorreu a sua passagem de mulher apaixonada e amante a rainha, mesmo depois de morta? E como é que, depois de mais de sete séculos, ela continua sendo uma ausência presente na história de Portugal, na ficção e, segundo Sousa (2005), um tema português de repercussão mundial?

Inês de Castro é um tema abrangente, instigante, apesar dos poucos documentos que existem sobre a sua vida, a sua família, ou mesmo sobre o seu amor por D. Pedro. No entanto, do pouco que dela se sabe, tem sido pretexto temático ciclicamente revisitado e reelaborado Sousa (2005), sobremaneira ao nível de múltiplas produções artísticas, mediação sem limites na exploração do que, do muito já foi escrito sobre ela, ficou nebuloso, sem solução ou foi apagado, buscando explicar ou desvendar mistérios. Autores como Sousa (2005) e Vasconcellos (2005) destacam que ela foi uma mulher sem vOz e sem brilho individual. Sempre foi falada, mas não há registo escrito da sua vOz na primeira pessoa. A única fala imputada a ela é a do encontro com D. Afonso IV, aquando do presumível anúncio da sua condenação à morte, e, mesmo assim, o acontecimento é questionado pelos historiadores. Vasconcelos, a esse respeito escreveu: 
O episódio em que se conta que D. Afonso IV, para fazer executar a sentença capital, foi pessoalmente, à casa habitada por Inês, acompanhado de cortesãos e, certamente do carrasco, é inverossímil e não resiste, a um pouco de reflexão. Inês veio-o receber à porta, e com a apresentação de seus filhos, e com abundância de lágrimas e palavras piedosas, pede misericórdia, conseguindo mudar os sentimentos ao velho pay sesudo, que se comove e resolve indultar, mas a intervenção intempestiva de alguns cavaleyros que com el rey hião pera morte dela obsta que a benignidade régia surta efeitos, obrigando o monarca a consentir que eles voltem atrás para a fazer matar. (VASCONCELLOS, 2005 , p. 14-15, grifos no original).

Essa cena, segundo o autor, vai contra aquilo que a historiografia sabe sobre $\mathrm{D}$. Afonso, pois parece referir-se mais a um delírio literário do que a um acontecimento. Assim, a dúvida sobre o único indício de que Inês algum dia teve voz fica desfeito ou em suspenso, referendando o silêncio em torno dela. No entanto, Sousa (2005, p. 38), não considera resolvida a questão do encontro e da fala de Inês com o rei, como o faz Vasconcellos (2005). Aquela estudiosa propõe uma comparação com a narrativa inscrita nos baixos relevos do túmúlo de Alcobaça, dado que lhe

[...] parece incontestável que, como as lê António de Vasconcellos, as edículas 41 e 42 (a de 2 horas, segundo Montalvão Machado) revelam uma viragem da situação: Inês dominada pelo carrasco surge depois vitoriosa. Esse triunfo efémero presume uma contra-ordem do Rei que determinara já a sua morte. Tal mudança de atitude ajusta-se à versão praticamente invariável da entrevista: o Rei apiedou-se dela e quis perdoar-lhe. (SOUSA, 2005, p. 38-39).

Admitindo-se que tenha havido esse encontro com o Rei, o que se tem é um silenciamento de Inês de Castro, em parte devido às condições sóciohistóricas da Idade Média, em que, de acordo com Nascimento (1997, p. 85), as mulheres "estavam obrigadas a circular exclusivamente na esfera privada. E, ainda assim, estaríamos falando de uma circulação somente permitida dentro dos limites da casa paterna, da casa marital ou do convento." Outra razão talvez tenha sido a sua condição de amante do infante. No entanto, de acordo com Sousa
(2005) a cena do encontro de Inês de Castro e D. Afonso IV e, portanto a sua vinda a Coimbra está descrita no túmulo de Inês de Castro, em Alcobaça, e esta foi a fonte documental em que Fernão Lopes - cronista régio - teria obtido essa informação, a qual é refutada pelos historiadores. A justificativa para desconsiderá-la é o fato de os atos (imagens) que estão no túmulo terem sido 'inventadas', não podendo ser, por isso, fonte histórica.

De acordo com Vasconcellos (2005), há informações de que D. Pedro e Inês de Castro trocavam frequentemente de residência e uma das razões, segundo muitos, devia-se à rejeição da população a Inês, e não ao Infante. Outra explicação para as constantes trocas de residência talvez resida no fato de os reis e demais membros da família real costumarem mudar de cidade com frequência. O mesmo autor salienta ainda o perigo do anacronismo nas projeções retrospectivas, ao sublinhar que a lenda que elevou Inês de Castro a mito permaneceu durante muito tempo no âmbito da Literatura, sem interessar ou emocionar o povo. Somente no séc. XVIII a narrativa começou a se tornar popular por meio da literatura de cordel. Só então o drama de Inês de Castro se terá "democratizado" no seio de uma população esmagadoramente analfabeta e sujeita a ouvir enaltecer as exemplaridades escolhidas pela Igreja, o que não era o caso De Inês de Castro. Assim, terá sido essa literatura não intelectualizada, lida ou ouvida, que penetrou nas classes populares, tornando conhecidos episódios como o da coroação e o do beija mão do cadáver.

As razões do interesse pela mulher também conhecida por "peito de garça" se deve às condições de sua morte, em Coimbra, e à intervenção de D. Pedro. De acordo com Coelho e Rebelo (2017), assim que se tornou rei de Portugal, D. Pedro iniciou uma campanha de legitimação de Inês de Castro e de seus filhos, através de "uma acção de afirmação e propaganda política muito concentrada e em contínuo crescendo" (COELHO e REBELO, 
2017, p. 11). Dentre as ações destaca-se a imposição do título de 'infantes' aos filhos, o estreitamento de relações com o mosteiro de Alcobaça e a declaração que fez em Cantanhede, de ter-se casado com Inês de Castro alguns anos antes da sua morte. $\mathrm{O}$ mais grandioso passo, segundo esses autores, foi, porém, o translado do corpo para Alcobaça com grande cerimonial que incluiu um imponente cortejo e uma celebração litúrgica laudatária e legitimadora da união dos dois, momento que teve as suas expressões máximas no sermão das Exéquias, proferido pelo Bispo D. João de Cardaillac, e no enterramento no túmulo em que ela é consagrada como rainha.

Por fim, na literatura, ela tornou-se um tema recorrente antes de Camões. No entanto, de acordo com Vasconcellos (2005), o grande vate foi o primeiro a cantá-la como musa e heroína. Sousa (2005) e em entrevista para a RTP, emissora Portuguesa de Rádio e Televisão, sustenta que a força de Inês vem de D. Pedro e dos acontecimentos protagonizados por ele, sendo que a derradeira ação foi a sua coroação, mesmo tendo sido mais simbólica que factual. Esses acontecimentos deram-lhe uma existência simultaneamente histórica e ficcional, com predominância das suas representações estéticas, especialmente, nas artes plásticas. Ainda de acordo com Sousa (2005, p. 63) "a coroação teve um êxito estrondoso [...] foi a cena inesiana que inspirou os grandes quadros românticos na Europa". Foi representificação dessa cena que popularizou o mito daquela 'que foi rainha depois de morta'.

Segundo Sousa (2005, p. 11), “a figura de Inês de Castro, que a História e a Literatura levaram ao conhecimento de praticamente todos os povos da Europa - e modernamente na América - tem sido reconstituída a partir de elementos de fontes diversas que ao longo dos séculos se foram reunindo". Diante disso, compreende-se que o nosso intento de eleger Inês de Castro como objeto discursivo procure mobilizar a história e a memória pela poética da ausência, junto à Análise de Discurso, e a partir de lugares, que também são linguagens', em que Castro é evocada como ausente, mais precisamente, a Quinta das Lágrimas - lugar onde teria sido morta - e em Alcobaça, onde estão os túmulos dela e de D. Pedro. Importante também será a análise do sermão de suas exéquias, proferido, de acordo com Coelho e Rebelo (2017, p. 15), pelo arcebispo de Braga D. João de Cardaillac, "quando da transladação dos seus restos mortais de Santa Clara para Alcobaça [...]".

Conforme Catroga (2009, p. 39), “o túmulo e o cemitério devem ser lidos como totalidades significantes que articulam dois níveis bem diferenciados: um visível e outro invisível". Estas duas camadas dissimulam a degradação decorrente do tempo e, mediante os signos e símbolos, simulam a não-morte, ou melhor, a morte (simbólica) da morte física. Entendemos que a campanha de legitimação de Inês de Castro lançada por D. Pedro, a transladação do corpo, a coroação e o enterramento no Mosteiro de Alcobaça e, também, devido ao enunciado "Até ao fim do mundo", esculpido no túmulo de Inês de Castro e a localização do túmulo do futuro rei em frente ao túmulo dela, dissimulam, de certa forma, a passagem do tempo, através da simbolização da vitória escatológica da vida sobre a morte. Trata-se, nos termos de Catroga, de uma monumentalização da expetativa justiceira e eternizadora do Juízo Final de cunho cristológico que, se é expressão de fé, também pretende afiançar aos vivos a restituição a Inês de tudo aquilo que o assassinato lhe tinha roubado.

A Quinta das Lágrimas é um espaço povoado de sinais que subtilmente remetem para o sangue e para a tragédia. Mostra-o os textos-imagem que de lá capturamos. São eles: o folder de divulgação dos jardins medievais, a Fonte dos Amores e a pedra com os versos de Camões alusivos ao local dos amores de Pedro e Inês e da morte desta. 


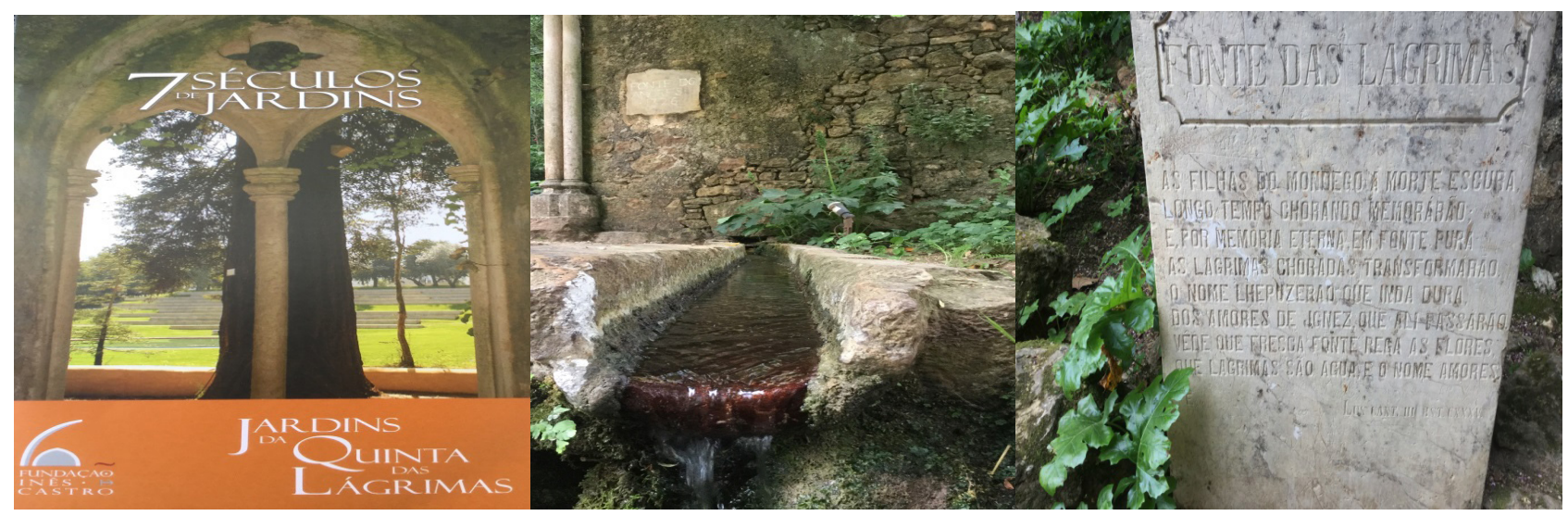

Textos-imagens capturados por Maria Cleci Venturini em 17 de abril de 2017.

Levando em conta esses textos, conclui-se que a Quinta das Lágrimas é parte constituinte do mito, mas também um 'lugar de memória' que ajuda a credibilizar os efeitos de veracidade veiculados, quer por discursos historiográficos, quer por narrativas orais e ficcionadas sobre Inês. Eles são fortes, não porque o local 'guarda' objetos, mas devido ao fato de a simbologia se fundir com uma natureza que, como museu vivo e a céu aberto, convoca a contemporaneidade dos acontecimentos. $\mathrm{E}$ o princípio de realidade é igualmente reforçado pela proximidade da Quinta das Lágrimas com o Mosteiro de Santa Clara-a- Velha, Mosteiro que tinha abrigado a Rainha Santa Isabel, avó de D. Pedro e falecida em 1325.

No entanto, ao conjunto conimbricense falta-lhe a sepultura da amante que os ditames políticos condenaram à morte, o que talvez explique porque é que a 'presença' da grande ausente se sinta com mais força em Alcobaça ou em narrativas que fizeram com que ela fosse "celebrada por los cronistas y sublimada por los poetas" (ASENSIO, 1965, p. 337). É verdade que as ervas avermelhadas que crescem no leito do curso de água que cai da fonte (dos Amores) são uma metonímia do assassinato. Porém, a gótica paisagem neomedievel que a circunda tem uma clara conotação romântica, maneira de germinar o amor trágico com a violência da morte, matrizes essencais dos grandes processos que conduzem à lenda e ao mito. Apesar de tudo, sente-se 'a falta da falta', isto é, o jogo da simulação, devido à inexistência do seu grande suporte: o corpo morto e o túmulo. Daí que a Quinta esteja mais vocacionada para ser um 'lugar' de revivescência de sentimentos de paixão e de tragédia, do que, ao contrário do que acontece em Alcobaça, um palco anunciador da promessa de ressurreição e de reencontro entre aqueles que a morte violentamente separou.

Defendemos esse posicionamento, mobilizando o argumento de Catroga (1999, p. 20) em relação aos cemitérios e museus, quando destaca que "o nexo entre a memória e o monumento, articulado com o jogo dissimulador dos símbolos funerários, obriga a ter-se cautela na qualificação do cemitério como museu”. Segundo o pesquisador o cemitério é

[...] uma das materializações privilegiadas da
memória-saber desde o século XVIIII. Cenário
de memórias-constrúdas, mas também de
memórias-vividas (principalmente no terreno
da gestão familiar do culto), as necrópoles são
os memoriais por excelência do século XIX e
do seu prolongamento no século XX, porque
as recordações que os símbolos sugerem não
revelam somente a ordem do saber - como
é típico do racionalismo iluminista e da
organização museológica ou biblioteca -, mas
mais a ordem dos sentimentos e das intenções
cívico-educativas. (CATROGA, 1999, p. 20-
21, destaques do autor).

Os três textos-imagens que acima reproduzimos constroem uma narrativa que cumpre o cânone clássico da tragédia, mas num contexto 
cristão. Por isso, a simbologia dos túmulos insinua a promessa na redenção escatológica, condição necessária para garantir a sobrevivência de Inês morta na memória dos vivos.

No primeiro texto (Quinta das Lágrimas), o enunciado "cinco séculos de jardins" referencia o século XIV e identifica Inês de Castro, mesmo que esse nome não esteja escrito em um espaço marcado. O não explícito sugere 'presença' e entendemos ser igualmente possível aplicar a noção 'poética do ausente' às diferentes versões do drama e do amor vivido (como crônica e/ou como mito) entre Inês e D. Pedro. Em sintonia com o imaginário popularizado por obras de ficção e por narrativas de cordel ou literárias, a semiologia do jardim da Quinta das Lágrimas encena-o como um palco adequado ao desfecho dramático dos amores proibidos por razões de poder.

Alicerçamos essa interpretação nas duas fontes: a das Lágrimas e a dos Amores e, também, nos versos em que Camões destaca a linda Inês, segundo Vasconcellos (2005, p. 16), “desde a estância 118 até 136 do Canto III, de Os Lusíadas (1572)". O grande épico foi quem deu "forma literária à lenda, introduzindo nela ficção poética nova, de uma delicadeza e ternura de que só o seu génio singular era capaz”. Alguns passos estão esculpidos em pedra junto à Fonte das Lágrimas, funcionando, assim, como um dos suportes pétreos de mediatização representificadora de Inês de Castro num cenário gótico, isto é, num jardim medieval, cujas sinalizações indicando que a vegetação e a flora têm ali liames de sete séculos de histótia natural.

Neste quadro, a Quinta das Lágrimas é a raiz primacial de onde promana a imaginação que alimenta a memória mitológica inesiana, sendo a Fonte dos Amores o espaço mais suscitador de emoções. A lenda foi vendo nas manchas vermelhas que se veem no pequeno lago os "vestígios" do sangue vertido por Inês, que teria sido morta nesse lugar em 1355. As razões que ditaram este desenlace foram dominantemente políticas: uma esteve relacionada com os irmãos de Inês; a outra resultou das incomodidades que a ilegitimidade e o futuro dos filhos do casal estava a levantar junto da corte. Essa tese pode ser reforçada pela negação do casamento entre Pedro e Inês, feita por Fernão Lopes (1380-1439), cronista régio que tinha a incumbência de registrar os acontecimentos importantes da corte.

Seja como for, cantado por poetas e por dramaturgos, o drama de Inês foi subsumindo a referencialidade histórica, o que não admira, pois a sua trama era passível de traduzir valores e tensões de porte universal, como aquelas que tecem a velha dialética entre Eros e Thanatos, aqui exemplarmente plasmado nos nomes - Quinta das Lágrimas. Fonte dos Amores - que localizam e no sangue que ininterruptamente as águas desta última irrigam sem o conseguirem apagar.

Vasconcellos (2005, p. 19) propôs-se 'fazer a exposição da lenda', mostrando os pontos em que ela se afasta daquilo que, comprovadamente, a historiografia conseguiu apurar. Um deles diz respeito justamente à Quinta das Lágrimas. Contextualizando as regras e os costumes da época, e recorrendo à base documental disponível, defendeu que "os amores de Pedro e Inês não podem, em face da história, localizar-se exclusivamente num determinado ponto do país, marcar-se num cenário a esse suposto idílio, que se prolongou por largos anos", pois eles viveram em diferentes lugares e, no período que antecedeu o assassinato, habitaram o paço da Rainha, junto ao Mosteiro de Santa Clara. Ademais, não foi nos terrenos atualmente denominados "Quinta das Lágrimas" que ela foi morta, em 1355, mas naqule Mosteiro e às mãos, não de conselheiros do rei Afonso, mas de um carrasco.

A poética da ausência pode ser definida como o modo de tornar presente o que não existe mais. Ora, no que tange a Inês de Castro, podemos 
sustentar que, no túmulo em Alcobaça, estamos perante uma produção simbólica não só de cunho explicitamente funerário e tumular, monumental e comerativa, mas também planificado até ao mínimo pormenor, como os baixos-relevos do túmulo bem demonstram. É que a demanda por legitimação de seus filhos, e para que, mesmo postumamente, Inês fosse rainha, por ordem do Rei Dom Pedro I foi criado, segundo Coelho e Rebelo (2017), um espetáculo apoteótico em três atos: o solene cortejo de transladação do corpo de Inês de Castro, vindo de Coimbra; a celebração litúrgica em que o bispo de Braga, D. João de Cardaillac, proferiu o sermão das exéquias; e a sua coroação simbólica: o corpo de D. Inês foi deposto num túmulo, esperando pelo rei, o qual, de acordo com a simbologia da estátua jacente e com a iconografia esculpida na arca tumular, a consagra como rainha e bemaventurada, completando o ciclo da "afirmação, propaganda e sacralização do casamento entre os dois amantes" (COELHO e REBELO, 2017, p. 14). Por meio desses três momentos, o então rei de Portugal almejou eternalizar Inês de Castro, redimir a sua memória, fazendo-a 'presente' na sua irremediável ausência, pelo menos até "O fim do mundo", como está escrito no seu túmulo.

\section{Túmulo de D. Inês de Castro}

Inês de Castro, a nobre galega por quem o infante D. Pedro

se apaixonou, foi executada em 1355, em Coimbra, por ordem

do rei D. Afonso IV.

O túmulo tem representadas cenas da vida e morte de Cristo,

em analogia com a que foi a sua vida. O Juízo Final sela a narrativa,

com a salvação dos inocentes e a condenação dos culpados.

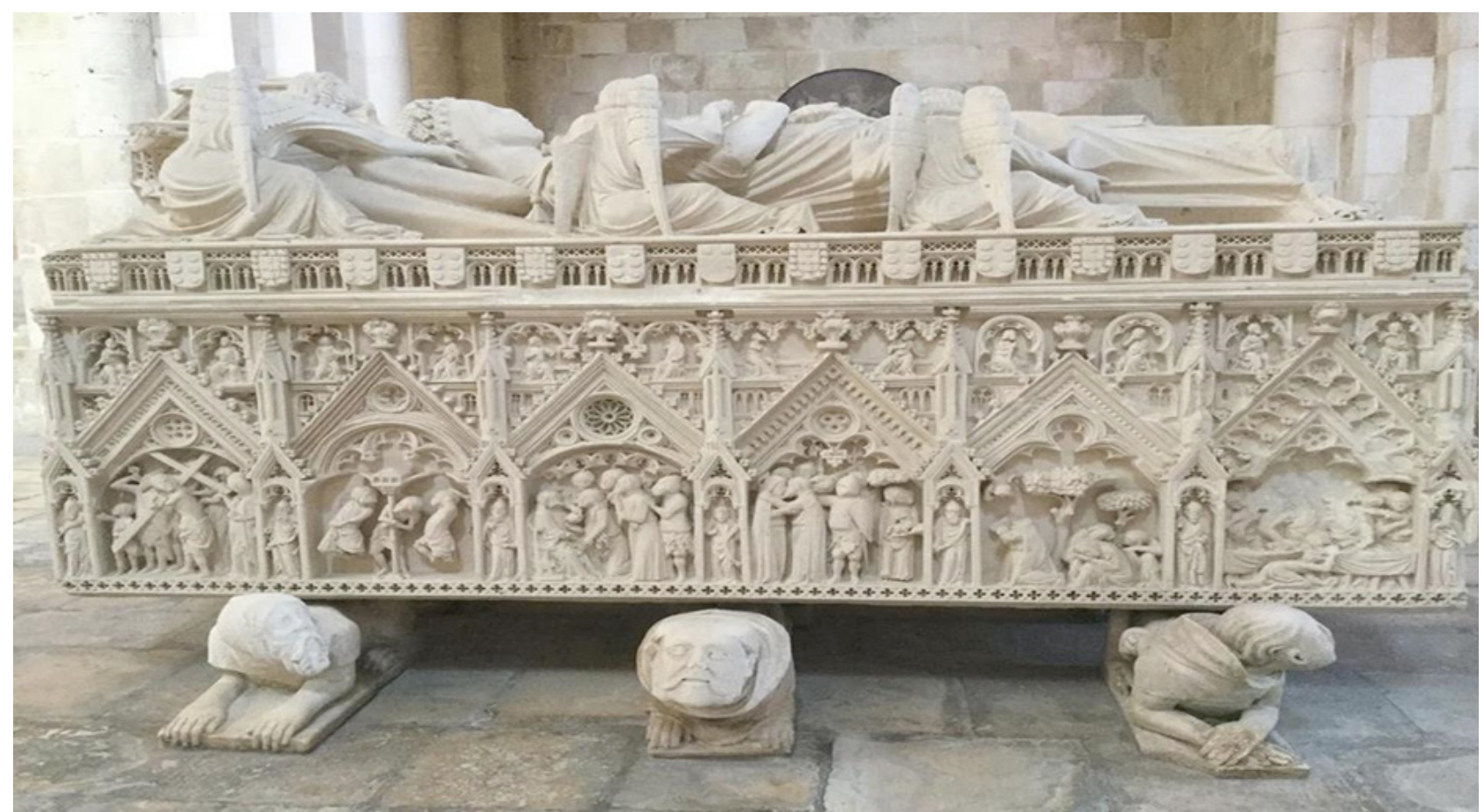

Textos-imagem capturados por Maria Cleci Venturini, em 24 de agosto de 2017. Mosteiro de Alcobaça - PT 
Aquela que, simbolicamente, começava a ser rainha, foi panteonizada com todas os sinais de distinção próprios da época, aqui levados às últimas consequências por razões políticas, incluindo as inerentes à política da memória. Dom Afonso IV tinha sido sepultado na Sé de Lisboa, mas, em Alcobaça, jaziam os restos mortais de Dom Afonso II e de Afonso III. Porém, não por acaso, o túmulo de Inês foi implantado, por ordem do novo rei, no lugar mais central e escatologicamente mais importante da igreja do mosteiro (e em todas as igrejas): o altar com o seu sacrário. Podemos perceber à luz das projeções sociais no modo de representar as esperanças de salvação post-mortem, as desigualdades que dividiam a cidade dos vivos sempre se espelharam na organização do simbólica na cidade dos mortos.

Destarte, não admira que o princípio cristão da igualização na morte, bem como o cariz comunitarista da ressurreição final dos corpos, e das preces pela salvação dos finados, recebessem traduções que legitimavam as desigualdades e hierarquizações que estruturavam as sociedades cristãs medievais. O que se refletia na geografia cemiterial coberta pelo "tecto eclesiástico" (as igrejas e seus adros): o povo era comummente enterrado em vala comum, no soalho ou nos adros das igrejas, enquanto o clero e a nobreza foram conquistando direitos de indentificação, de individualização e de persolização tumular, com os túmulos das altas dignidades a conquistarem uma gradual aproximação da zona mais sacral do lugar do culto, aquela que, por isso mesmo, ofereceria uma maior garantia de acesso do morto-dormente à porta que daria entrada, na hora do fim dos tempos e da ressurreição final dos corpos, na definitiva bem-aventurança na Jerusalém Celeste, instância compensadora de todos os pecados e injustiças terrenas.

$\mathrm{Na}$ placa, que identifica o túmulo de Inês, repercute-se a intenção de denúncia que atravessa muitos discursos e memórias em torno de execução de 1355. E para o mesmo sentido apontam as representações inseridas no túmulo. Nelas, objetivando uma tendência em curso, mas que só se desenvolverá mais intensamente nos séculos seguintes, se individualiza e personaliza, ao mesmo tempo, a mulher - Inês de Castro - e o seu mandante algoz - e D. Afonso IV, num contexto que também dá visibilidade à presença do povo, destinatário último da narrativa. O efeito de sentido da denúncia decorre da palavra "executada", que não significa condenação, mas uma morte gratuita, sem imputação de crime.

$\mathrm{Na}$ senda do que Catroga (1999, 2000) escreveu sobre a memória e o último rito de passagem, vemos no enterramento de Inês no espaço sagrado do mosteiro a aplicação da crença cristã no Juízo Final e na ressurreição final dos corpos a uma política de memória (e a uma memória política) concreta e reparadora. Daí que também concordemos com esta recente interpretação que Coelho e Rebelo (2017, p. 15) fizeram do acontecimento: o segundo enterramento de Inês e a sua respectiva sacralização "no espaço sagrado de um prestigiado mosteiro cisterciense, que a recebia como mulher legítima de D. Pedro", projetava-a espiritualmente "para a bem-aventurança eterna dos eleitos no Paraíso". Este horizonte também dá sentido escatológico à construção do túmulo de $\mathrm{D}$. Pedro em frente do túmulo de Inês de Castro. De acordo com a lenda, isso foi projetado para que, no dia do Juízo Final, os dois se (re)encontrassem "olhos nos olhos".

Pelo funcionamento da noção de 'poética da ausência' a partir de Catroga (2000, p. 167), é possível sublinhar que a liturgia do enterramento de D. Inês funcionou, literalmente, como uma metáfora do corpo, negando a morte, na medida em que, no túmulo, ela está coroada e ricamente vestida. Nesse mesmo lugar, "destacam-se ao fundo, figuras de anjos envoltos em nuvens, que 
nos evocam a espacialidade celeste" (COELHO e REBELO, 2017, p. 28). Sublinhamos, ainda, a representação de Jerusalém, o beijo do Judas, o calvário de Cristo, entre outros destaques. Tratase da narração contando como 'teria' sido a sua morte e, com isso, gerando controvérsias, já que os poetas dizem que foi com punhal, mas de acordo com Sousa (2005), foi por degolamento e isso pode ser lido no túmulo.

Ainda segundo Coelho e Rebelo (2017, p. 29-30), D. Pedro, no seu desejo de vingança, exigiu que "o retrato dos traidores e assassinos, sob a forma de monstros, com rostos humanos, imberbes ou barbados, encapuchados, e com o corpo de animal, se estampasse nos suportes do túmulo, condenando-os a suportar o peso da sua vítima, da sua culpa". Entendemos, assim, que a representação narrada nos baixos relevos seja, em consonância com a mundividência religiosa dominante na Idade Média, dual e maniqueia: de um lado, estão figurados os bons, merecedores da beleza e da serenidade; e, do outro, estão os maus, feios, desproporcionais e com indicação de sofrimento nas faces, modo de dizer que os primeiros se encaminham para a redenção dos justos e os segundos para a condenação infernal. Essa re-presentificação agrega ao túmulo valor simbólico e alegórico das esfinges, conforme era costume na tumulária da Antiguidade.

Finalmente, a terceira materialidade e derradeira marca da campanha de legitimação de Inês de Castro como esposa de D. Pedro e como rainha de Portugal resulta, segundo Coelho e Rebelo (2017, p. 15), do sermão proferido pelo arcebispo de Braga, D. João de Cardaillac, uma espécie de "monumento literário que dialoga com um monumento escultatório". Ainda segundo os mesmos autores

Nesse texto se consubstancia o elogio da defunta, mas também a defesa de uma tese política, a par da enunciação de uma filosofia escatológica que só terá ecos em Portugal um pouco mais tardiamente, no decurso do Quatrocentos, de que é paradigma exemplar o "Horto do Esposo". (COELHO e REBELO, 2017, p. 15).

O sermão, da mesma forma que o monumento tumular, foi marcadamente político, defendendo o casamento de D. Pedro e Inês de Castro, logo o estatuto de Inês como rainha, e, com isso, a legitimação dos filhos como Infantes. $\mathrm{O}$ arcebispo fez uso da sua sabedoria com vista a impressionar o auditório, boa parte do qual, segundo Coelho e Rebelo (2017), tinha sido convocado pelo rei para assistir à cerimônia de transladação e de tumulação. A peça valorizou a Sagrada Escritura, priorizando o Antigo Testamento com vista a mostrar a sabedoria e a erudição do Arcebispo. O tema de abertura do sermão foi a matriz fundacional genesíaca e o exemplo de Abrahão - o primeiro dos patriarcas e rei dos povos - que, tal como Dom Pedro, publicamente sepultou a 'verdadeira' esposa Sara, honrando-a, assim como Inês estava a ser honrada por seu esposo.

O sermão invoca os fundamentos judaicocristãos que ditaram a rejeição das práticas cremacionistas pagãs em nome da superioridade da inumação, aceitando o preceito bíblico "tu és pó e em pó te hás de tornar”. Há também a aceitação do cemitério como 'dormitório', onde o morto espera, dissimulando a sua corrupção e esperando a ressurreição final dos corpos. Para significar esta expectativa, o arcebispo lança mão da analogia entre o trigo que cai na terra, e que, para poder germinar, "morre e apodrece, para reviver e renascer com o calor do sol", e o cadácer inumado, "o qual igualmente fica encoberto e apodrece na terra, para ressurgir com vida no dia da ressureição" (COELHO e REBEL, 2017, p. 19).

A partir dessa introdução (exórdio) o arcebispo inicia a invocação de valores, quais sejam: os de caráter, (dados pelos véus dos costumes); os 
do corpo (no pó da terra); e os da alma (no extremo dos céus). No desenvolvimento das três premissas, chama a terreiro a moral, os bons costumes, a renúncia a tudo que é da ordem do humano, como a vaidade e as glórias, definindo-se a si mesmo como o pastor que busca a salvação do seu rebanho.

Outra característica bastante presente é a celebração da humildade, da caridade e da vida cristã de Inês de Castro, a qual, segundo o arcebispo, porque era humana também errou, mas fez penitências e pediu perdão. Há também referência ao valor moral e pedagógico da morte, pois esta patenteia a finitude humana, de quem ninguém pode escapar, a compreender melhor a efemeridade das glórias, das vaidades e dos bens mundanos. Daí a ênfase que pôs nesta ideia: "tudo e todos são nada na similar aniquilação pela morte, do rico ou do pobre, do senhor ou do servo, do rei e do súbdito, do forte ou do fraco, do belo e do feio. É a dança da morte, igualitária, implacável, absoluta, que entra no palco numa cerimônia religiosa" (COELHO e REBELO, 2017, p. 21). Enfim, Inês - ausente - torna-se presente pelo desejo de eternização, acreditando na ressureição, dando-lhe o que lhe tinha sido negado.

Em simultâneo, porém, o espetáculo da trasladação e da coroação, bem como a narrativa inserta na monumentalidade funerária inesiana visavam a outro nível de eternização: aquele que decorre da transmissibilidade garantida pela memória dos vivos. Ora, se a parte movente da cerimónia foi um espetáculo efémero a fixação pétrea da morte de Inês, agora fixada como oficial, também quis dar a ver e a ler uma versão que pudesse corrigir outras e, sobretudo, reabilitar a visão popular da evocada, fazendo dela uma rainha, ainda que só postumamente amada pelos seus súbditos.

\section{Efeito de fechamento: re-presentificação e reforço do mito}

É hora de pôr um ponto final, mesmo provisório, neste ensaio. Foi nosso propósito 'tentar' caminhar no entremeio entre a memória, a história e o espaço público e 'pensar' um diálogo com Fernando Catroga. Como a redundância e a repetição constituem a memória convocada pela história, precisamos dizer e reiterar que, assim como os ritos tanatológicos e a escrita da história têm em comum a função social de tornar, mediata e mediaticamente, presente o que já não existe, também nós buscamos "dar futuros ao passado", reiterando que o diálogo com Fernando Catroga é metafórico, pois, do muito que ele diz, do muito que já disse, do muito que deixa de dizer, e do muito que queríamos ouvi-lo dizer, fica ainda uma 'demanda' - a continuidade, montada na certeza de que ainda há muito a ouvir, ainda há muito a ler, e o ciclo não se fecha. Com certeza, ele se abre e isso porque se constitui pelo impossível, que é querer estar no lugar do outro, que é experimentar sair da nossa zona de conforto. Diante disso, eu penso nas quantas e nas muitas vezes, nesse ano de 2017, que eu disse: eu sou de Letras... Não sei se foi resistência, se foi persistência, se foi justificativa para a ausência, que talvez não chegue a ser presença.

De qualquer modo, a questão que permanece é: entendemos a poética da ausência? Arrisco a dizer que Inês de Castro é o exemplo da ausência e por meio dela é possível 'ver' como as diferentes linguagens re-presentificam o ausente, o que já não é... mas passa a ser. Ela é 'ausência' na Quinta das Lágrimas, mas Coimbra a coloca lá... As lacunas da história, colocam-na lá, ela ressoa pelas fontes, pelas temáticas enesianas e sempre aparece uma questão a mais ... É o detalhe que faz sentido... A 
narrativa está nos túmulos e Maria Leonor Machado de Sousa sustenta que eles são documentos, mas Vasconcellos (2005) lança mão desses mesmos indícios para dizer que é ficção. Um diz... outro desdiz... e mito se fortalece. Inês de Castro continua sendo um tema recorrente em Portugal, na Europa e também no Brasil. Em Alcobaça, no lançamento do livro "D. Pedro e D. Inês: diálogos entre o amor e a morte", vimos como, após sete séculos, Inês de Castro é sempre presentificada. E ela não é santa, mas é morta... Vimos também o expressivo número de obras em que ela é tema, mais uma vez, vimos que o espaço público, mesmo o mais renomado, busca um nome e por esse nome se faz... Vimos que a ideia de morte que funciona hoje, não é muito diferente daquela do passado. Se lá, no passado, dentro da igreja, cabiam somente as elites, na modernidade os cemitérios passaram ser espaços públicos, mas a igualdade, continua a não existir... Só alguns "retornam ao pó”...

\section{Referências}

ASÊNSIO, Eugénio. De la crónica al mito. Lisboa: Boletim de Filologia, 1965.

BERNARDES, Joana Duarte. Para além da imaginação histórica: memória, morte, fantasia. Tese de doutoramento em História - Faculdade de Letras da Universidade de Coimbra, 2004.

CANDAU, Joel, Mémoire et Identité, Paris, PUF, 1998

CATROGA, Fernando. O céu da memória: Cemitério Romântico e Culto Cívico dos Mortos em Portugal (1756-1911). Coimbra: Livraria Minerva Editora, 1999.

O culto dos mortos como uma poética da ausência. ArtCultura, Uberlândia, v. 12, n. 20, p. 163-182, jan.-jun. 2010.

Memória, História e historiografia. Coimbra: Editora Quarteto, 2001.
- Os passos do homem como restolho do Tempo.

Memória e fim do fim da História. Coimbra, Edições Almedina, 2009.

COELHO, Maria Helena da Cruz e REBELO, António Manuel Ribeiro. D. Pedro e D. Inês: diálogos entre o amor e a morte. "Sermão nas exéquias de D. Inês de Castro" de D. João de Cardaillac. Edição crítica, tradução e comentário Filológico. Coimbra: UC, 2017.

COURTINE, Jean-Jacques. Chapéu de Clémentis. Observações sobre a memória e o esquecimento na enunciação do discurso político. In: INDURSKY, Freda e FERREIRA, Maria Cristina Leandro. Múltiplos territórios em Análise de Discurso. Porto Alegre: Editora Sagra Luzzato, 1999.

CERTEAU, Michel de. L' écriture de l'historie. Paris, Gallimard, 1975.

MARCELINO, Douglas Átila. Historiografia, morte e imaginário: Estudo sobre racionalidades e sensibilidades políticas. São Paulo: Alameda, 2017.

MARIANI, Bethania Sampaio. O PCB e a imprensa: os comunistas no imagináriodos jornais (19221989). Rio de Janeiro: Revan; Campinas, SP: Unicamp,1998.

NASCIMENTO, Maria Filomena Dias. Ser mulher na Idade Média. Textos de História, Brasília, v. 5, p. 82-91, 1997.

Disponível em: <http://periodicos.unb.br/index. $\mathrm{php} /$ textos/article/view/5807/4813>. Acesso em: 01 jan. de 2018 .

ORLANDI, Eni. As formas do silêncio: nos movimentos dos sentidos. $5^{\mathrm{a}}$. ed. Campinas, SP: Editora da UNICAMP, 2002.

PÊCHEUX, Michel. Semântica e discurso: uma crítica à afirmação do óbvio. Campinas/SP: Editora da UNICAMP. 1997.

VENTURINI, Maria Cleci. Imaginário urbano: espaço de rememoração/comemoração. $1^{\mathrm{a}}$. ed. Passo Fundo: UPF Editora, 2009. 
VOUGA, Carvoeiro do. Apresentação geral. In: MATTOSO, José (direção); SOUSA José de Vasconcellos e (Coordenação). História da Vida privada em Portugal: Idade Média. Lisboa: Circulo de Leitores e Temas e Debates, 2010.

Submissão em 28 de dezembro de 2017.

Aceite em 12 de janeiro de 2018. 